\title{
Innovation Ecosystems in the Automotive Industry between Opportunities and Limitations
}

\author{
Ricardo Henrique da Silva \\ Doctoral Candidate, Department of Mechanical Engineeringa, and Researcher, Department \\ of Mathematics and Industrial Engineering ${ }^{\mathrm{b}}$, ricardohsilva@usp.br \\ Paulo Carlos Kaminski \\ Full Professor, Department of Mechanical Engineeringa, pckamins@usp.br \\ Rafael Ortega Marin \\ Consultant ${ }^{c}$, rafaelortegamarin@gmail.com \\ a University of São Paulo, Butanta, São Paulo - State of São Paulo, Brazil \\ b Polytechnique Montreal, 2500 Chemin de Polytechnique, Montréal, QC H3T 1J4, Canada \\ c Gradus Management Consulting, São Paulo, Brazil
}

\begin{abstract}
$\mathrm{T}$

he creation of effective innovation ecosystems (IES) at the national or sectoral level remains a difficult and not always feasible task. Basing on evidence from the Brazilian automotive industry, a case of unused opportunities for building a strong IES is considered. This is due to the insensitivity of such ecosystems to new complicated configurations and the formats of non-traditional interaction that they suggest - a "new ecology of competition", etc. The internal

context of companies in relation to the practice of open innovation has been studied. Despite joint projects with close value chain partners, carmakers are showing a closed attitude to external collaboration, unlike players in industries such as aerospace or information and communications technology that gained growth and major transformation by building a broader IES. Only a high demand from the government for creating a strong IES can change the situation.
\end{abstract}

Keywords: innovation management; automotive industry;

innovation ecosystem; open innovation

Citation: da Silva R.H., Kaminski P.C., Marin R.O. (2021)

Innovation Ecosystems in the Automotive Industry between Opportunities and Limitations. Foresight and STI Governance, 15(3), 66-80. DOI: 10.17323/2500-2597.2021.3.66.80 


\section{Introduction}

The automobile industry as well as other industry groups are experiencing unique moments within their life cycles. These groups evolved for several years into what is commonly referred to as an industrial innovation cluster [Swann, Prevezer, 1996] given that they geographically consolidated their suppliers, customers, labor, and even competitors to benefit from their scale in order to generate value for their respective stakeholders [Baptista, Swann, 1998; Beaudry, Breschi, 2003; Bell, 2005; Yang et al., 2009; Hering et al., 2011]. With the integration of developing countries into global markets, industries had to adapt again to what was called Global Value Chains [Humphrey, Schmitz, 2002] in order to face the increasing competitive pressure posed by new low-cost entrants [Sturgeon, van Biesebroeck, 2011]. However, more recently, these movements have not been enough to keep these industrial groups alive as new demands for innovation began to be imposed upon them by end users and governments. Not to mention the fact that more and more end users are increasingly considering urban cars as an expensive, complex, and unsustainable means of transportation, as one must commit a considerable part of one's personal budget for the purchase and maintenance of one's own personal vehicle [Wright, Train, 1987; Prettenthaler, Steininger, 1999; Wu et al., 2015]. The total ownership cost involved is a heavy burden due to the regular maintenance involved, rapid depreciation, and other associated costs such as insurance and governmental taxes. Moreover, the current transport sector has been identified as the main contributor to greenhouse gas emissions worldwide, something that has drawn the attention of regulatory bodies around the world to draft restrictive laws [Graham-Rowe et al., 2011; Poudenx, 2008; Beirao, Sarsfield Cabral, 2007]. As in other industrial sectors, such as Information and Communication Technology (ICT) [Fransman, 2010] and Aerospace [Armellini et al., 2011; Thompson et al., 2012], the auto industry will need to re-invent itself by understanding, and more specifically, acting as part of a wider and broader 'ecosystem' if it wants to survive all these new demands imposed on it by society.

The objective of this article is two-fold. First, the authors aim to assess whether the automotive industry is taking the first steps toward the formation of a new mobility innovation ecosystem that emerges from the changes in the industry as demonstrated in Figure 1. Second, it is to verify whether there is a positive relationship between practicing OI and the degree of innovation obtained. It is expected, from previous theory, that players that have already implemented OI practices should benefit in some way from these practices by observing, mainly, improvements in their innovation processes and/or in the degree of innovation. This will be accomplished by a questionnaire-based survey with pre-selected individuals who work for the automotive industry in Brazil in positions related to product development or innovation management.

The survey is mainly descriptive and was designed and applied to obtain insights into whether the auto sector in Brazil is pursuing Open Innovation (OI) by implementing some of its common practices. The survey also aims to assess how mature those practices are and what the main barriers are to its evolution. Previous theory already shows that OI practices are an indicator showing whether firms are preparing to open themselves to outside collaboration by integrating into a broader innovation ecosystem [Bogers et al., 2017]. Brazil is an interesting country in which to conduct this research as its automotive industry produced close to 3 million units in 2019 and, besides, it has car manufacturers of Asian, European, and North American nationalities operating on its territory. This, in turn, brings their respective cultures into the routine of their operations, be it in the manufacture or in the development of their vehicles. In addition, automakers in Brazil have a variety of strategies regarding the development of their vehicle platforms, having some primary leadership in the case of small car platforms and, at the same time, having a secondary role in the development of other larger platforms. The following sections of this article will be dedicated first to presenting a review of the literature on the pattern of evolution of regional industrial clusters toward global ecosystems of collaboration and innovation. The remaining sections present the research methodology applied followed by the results of the study. Finally, a section with final remarks and directions for future research initiatives is also presented.

\section{Theoretical Background}

\section{Moving from cluster to innovation ecosystems}

The economic performance of a country is composed of the economic performance of its regions and subregions, which in turn have their performance directly linked to the presence and strength of their industry 'clusters' that operate within their geographic territory [Lines, Monypenny, 2018]. "Clusters are geographic concentrations of industries related by knowledge, skills, inputs, demand, and/or other linkages" [Delgado et al., 2016]. When conditions are present such as a high level of technological opportunity, complex and systemic technical knowledge basis, and high "appropriability and high cumulativeness" [Iammarino, McCann, 2006], innovators will tend to be geographically concentrated, giving rise to emergent clusters. Even though geographically concentrated, regional industrial clusters are placed in a much broader global value chain [Humphrey, Schmitz, 2002]. Firms that operate in innovation clusters are more innovative and have great overall performance because they have access to a variety of intermediate inputs at a cheaper

http://www.anfavea.com.br/, accessed 28.11.2017. 
price and also have large pools of skilled workers at their disposal [Beadry, Swann, 2001]. However, there are also negative aspects of operating in clusters such as increased competition arising from congestion that can undermine a cluster's ability to growth and evolve [Beaudry, 2001; Broekel, Boschma, 2012].

When there is geographical proximity, coordination between players is enhanced by the reduced distance between them to the point where informal links begin to appear, forming a collaborative ecosystem. “(...) where constant creative feedbacks between individuals, communities and organizations occur" [Bathelty, Cohendet, 2014]. Studies show that engineers from industrial clusters acquire valuable knowledge through these informal networks and, at the same time, they share valuable knowledge with their informal contacts, which represents an important channel of knowledge diffusion within the cluster community [Dahl, Pedersen, 2004]. This temporary location proximity drives the formation of knowledge networks that increases the proximity levels between members in the long term, so that even if they are geographically apart [Balland et al., 2015; Torre, 2008], they will keep exchanging and diffusing knowledge using tools such as business conferences, presentations, conversations, peer discussions, and observations [Henn, Bathelt, 2015]. This collaboration has become necessary in order to deal with the growing complexity of technologies, projects, products, and services and acts as an incentive to improve the "generation, valuation and validation of ideas" [Koen et al., 2014]. It also increases the capacity of organizations to innovate, allowing the construction of connections between disciplines and industries, sectors [Dahlander, Gann, 2010], universities [Walsh et al., 2016], and end users [Parmentier, Mangematin, 2014], thus forming what has been called an OI system [Chesbrough, 2003].

OI became a new innovation paradigm as it clearly sets the notion of a firm's 'boundaries' [Santos, Eisenhardt, 2005] and presents the various advantages for operating in an 'open' model versus a 'closed' model [Gassmann, Enkel, 2004] by making a firm's boundaries permeable to outside-in and to inside-out knowledge flows [Wilhelm, Dolfsma, 2018]. Innovation and business models have since unfolded into more open and interactive arrangements [Chesbrough, Appleyard, 2007] in which the informal exchange of knowledge happens together with formal relationships [Autio, Thomas, 2014] in order to accomplish growth. "Partnerships and alignments, both downstream and upstream, became paramount for cross-fertilization and synergy" [Traitler et al., 2011]. Many industrial sectors have adhered to OI strategies and practices such as the bio-pharmaceutical [Bianchi et al., 2011], food [Sarkar, Costa, 2008], automotive [Marin et al., 2018; Ili et al., 2010], chemical [Sieg et al., 2010], and ICT [Bigliardi et al., 2012] among others. As firms learn, mature, and adapt to OI practices in general, the next step is to organize themselves into a broader and more diverse
Figure 1. Evolution toward the Formation of an Innovation Ecosystem

Source: authors.

group of actors throughout the various stages of their innovation process [Bogers et al., 2017], evolving into what has been called more recently innovation ecosystems' [Rohrbeck et al., 2009], or, depending on the perspective, 'business ecosystems' [Gomes et al., 2018]. Such has been the case of important sectors such as the ICT [Fransman, 2010] and aerospace [Thompson et al., 2012] innovation ecosystems.

Innovation ecosystems are a natural step for firms that initiated and adopted OI practices [Torre, Zimmermann, 2015]. Innovations in a networked industry environment, in general, are not the object of a single invention, but are the result of new products that are developed, new processes that are assembled, and even of new technologies, all brought together by a large variety of participants [Iansiti, Levien, 2002]. As soon as firms learn to cooperate and collaborate with outside actors and they start to see the innovation results from that collaboration, the next step is for them to move into a broader "industrial ecology system" [Torre, Zimmermann, 2015] or into a "new ecology of competition" [Moore, 1993]. Innovation ecosystems cross a variety of industries in which firms evolve their capabilities around any given innovation [Moore, 1993]. It might also be described as "the collaborative arrangements through which firms combine their individual offerings into a coherent, customer-facing solution" [Adner, 2006]. Complex innovations tend to involve a series of actors demanding changes and are not confined to their supply networks [Adner, Kapoor, 2010] as they also include other participants such as end users, governmental agencies, universities, and other coordinators or intermediaries that co-evolve within a "symbiotic relationship" [Iansiti, Levien, 2004]. Innovation ecosystems promote the interaction of innovation networks and knowledge clusters formally and informally, what “(...) catalyzes creativity, triggers invention and accelerates innovation across scientific and technological disciplines, public and private sectors" [Carayannis, Campbell, 2009].

\section{The new mobility innovation ecosystem}

Innovation ecosystems are the result of an evolutionary process and there is no single recipe that explains how innovation ecosystems emerge or are created as 
multiple formats emerge in the literature [Rabelo, Bernus, 2015], however they can be classified according to their maturity level [Moore, 1993], the roles and the dynamics present in the relationship between their participants [Kapoor, Lee, 2013] and, also, according to the platform [Gawer, Cusumano, 2014] or the value that is co-created [Benitez et al., 2020].

In the case of the auto industry, the new ecosystem it joins should go beyond current and traditional partners and be based on a wide range of actors and efforts. Many call this new innovation ecosystem Smart Mobility [Pulkkinen et al., 2019; Karim, 2017] as it involves efforts produced by a chain of actors that use intelligent sharing systems to provide end-to-end mobility [Ning et al., 2017]. Moreover it can go further and be called a Sustainable Mobility Ecosystem [Ma et al., 2018; Lyons, 2018] if, in addition, it prioritizes the use of low-carbon modes of transport and covers governments and regulatory entities [Banister, 2007]. This new ecosystem also embraces the current auto industry and all the technological changes that are occurring within its products, such as the introduction of engines powered by renewable energy [Rajashekara, 2013] and ICT technologies that are allowing automotive vehicles to become increasingly autonomous [Burns, 2013]. It also embraces a multitude of start-ups and new business models [Bellini et al., 2019] that are emerging and turning the vehicle into something shared and connected with other transport hubs that provide mass and micro mobility [Jittrapirom et al., 2017; Chong et al., 2011; Ho et al., 2018; Smith et al., 2018].

The size and coverage of the Mobility Innovation Ecosystem is also important to understand as are some basic practices that can take the current auto industry into a more innovative state. It is also critical to grasp how open the current industry is to these practices. Certainly, there are some intermediate steps before operating in a 'ecosystemic' mode. Several publications point to digitalization and OI as the background or even a necessary step on the path toward innovation strategies in a platform-based ecosystem [Bogers et al., 2017; Oberg, Alexander, 2019; West, Bogers, 2014; West et al., 2014]. These publications propose a positive correlation between OI practices and the formation and subsequent consolidation of an ecosystem afterwards. When firms start to practice OI, they open themselves to various kinds of interactions and knowledge flows between different types of development as well as commercialization players, even before a value creating ecosystem architecture is established. That movement is reinforced if the ecosystem being formed is platform-based, i.e., uses common standards to integrate products, services, and firms. This is a practice already known by the auto industry and has been used among its Tier 1 suppliers to develop its current products [Teece, 2018] for a long time already.

\section{Research Methodology}

The objective of this research is mainly descriptive because it seeks mainly to portray the collaboration pattern of a specific industry sector (the automotive industry) in a specific territory (Brazil), based on what has already been established in previous theory. The research methodology chosen by the authors involves collecting data from primary sources using a questionnaire-based survey [Forza, 2002] followed by the analysis of the data using a statistical software, such as Stata $^{2}$ for example, in order to deploy descriptive statistical analysis as well as a regression analysis. The sampling process used was non-probabilistic and was done per convenience due to the qualitative nature of the research. The questionnaire-based survey was designed to assess the interviewees' knowledge and experience and the common practices around OI at their respective companies. Since the 'Innovation Ecosystem' is a concept not completely understood within the auto sector yet, OI was the theme chosen to be surveyed as a proxy.

Brazil was the territory chosen to be surveyed mainly due to its heterogeneous automotive industry and the fact that it is capable of reflecting the corporate culture of the main automakers in the world. Although there is no genuinely Brazilian vehicle manufacturer on the international stage, the country is home to important automakers from Europe, Asia, and North America that have $\mathrm{R} \& \mathrm{D}$ and manufacturing operations on Brazilian territory and, consequently, end up reflecting the culture and strategies of their headquarters located abroad. In addition, the automobile sector is an important engine of the Brazilian economy (see Table 1), representing $18 \%$ of its industrial GDP, being the $6^{\text {th }}$ largest domestic market, and the $8^{\text {th }}$ largest worldwide producer $^{3}$, despite the economic crisis that hit the sector in 2014.

\section{Survey design}

The research questions were developed over a timeframe of approximately six months and included two interviews that were made with OI researchers to discuss the theoretical bases that supported the questionnaire, and another two interviews with innovation specialists from the automotive industry to evaluate and suggest improvements to the questionnaire. After this stage, the survey was tested on a small group of five industry respondents for fine adjustments. After completing this process, the survey was sent to the sample of professionals that were selected using an existing database of experts from one of the most renowned automotive graduate continuous education courses in Brazil. The survey was designed and applied to extract information about three major constructs related to OI that have already been explored in previous literature

\footnotetext{
Stata is a general-purpose statistical software package that belongs to StataCorp.

3 http://www.anfavea.com.br/, accessed 28.11.2017.
} 
Table 1. Brazilian Automotive Industry Overview in 2019

\begin{tabular}{|c|c|c|c|}
\hline \multicolumn{2}{|c|}{ Companies } & \multicolumn{2}{|c|}{ Factories } \\
\hline Automaker Brands & 26 & Industrial Units & 65 \\
\hline Autoparts & 473 & States & 10 \\
\hline Dealers & 5.249 & $\begin{array}{c}\text { Passenger } \\
\text { automaker } \\
\text { nationalities }\end{array}$ & 8 \\
\hline State name & \multicolumn{3}{|c|}{$\begin{array}{c}\text { List of passenger car manufacturers in } \\
\text { operation }\end{array}$} \\
\hline Bahia & \multicolumn{3}{|c|}{ Ford } \\
\hline Ceará & \multicolumn{3}{|c|}{ Ford (Troller) } \\
\hline Goiás & \multicolumn{3}{|c|}{ Hyundai, Suzuki, Mitsubishi } \\
\hline Minas Gerais & \multicolumn{3}{|c|}{ FCA, Mercedes-Benz } \\
\hline Paraná & \multicolumn{3}{|c|}{ Audi, Nissan, Renault, VW } \\
\hline Pernambuco & \multicolumn{3}{|c|}{ FCA } \\
\hline Rio de Janeiro & \multicolumn{3}{|c|}{ Nissan, Land Rover, PSA } \\
\hline Rio Grande do Sul & \multicolumn{3}{|c|}{ GM } \\
\hline Santa Catarina & \multicolumn{3}{|c|}{ BMW } \\
\hline São Paulo & \multicolumn{3}{|c|}{$\begin{array}{l}\text { Chery, Ford, GM, Honda, Hyundai, } \\
\text { Toyota, VW }\end{array}$} \\
\hline
\end{tabular}

as demonstrated in Table 2. Each construct was then broken down into measures and each measure was divided into questions or blocks of questions in the survey. Finally, each question was treated as a single variable during the statistical analyses carried out with the Stata software. In Table 2, the three main constructs and their respective measures are presented, together with the theoretical basis used to design the questions. In the first construct, 'OI Organizational Culture', the object was to list the main actors or partners involved in the practice of OI at the firm [Wilhelm, Dolfsma, 2018; Ili et al., 2010], as well as the main activities carried out through this partnership in addition to the reasons that motivated such association [Mortara, Minshall, 2011; Lewin et al., 2017]. Cultural aspects of the firm in relation to the practice of OI was also explored with the main objective of verifying whether there has been an increase in the practice of OI in recent years or not [Breunig et al., 2014].

The 'OI Barriers and Risks' construct encompasses all issues that address factors that hinder or block the implementation of OI projects by the firm [Ili et al., 2010]. Internal and external risks are addressed. In the case of internal risks for an organization, it is possible to list a corporate culture that does not favor OI, the opposition or even passivity of employees in addition to the lack of resources or investment [Aquilani et al., 2017]. As for external risks, they can include a lack of trust from partners, the possibility of theft or misappropria-
Table 2. Survey Structure

\begin{tabular}{|c|c|c|c|c|}
\hline Construct & Variable & \begin{tabular}{|c|}
$\begin{array}{c}\text { Theoretical } \\
\text { Basis }\end{array}$ \\
\end{tabular} & Scale & Questions \\
\hline $\begin{array}{c}\text { OI } \\
\text { Organiza- } \\
\text { tional } \\
\text { Culture }\end{array}$ & $\begin{array}{l}\text { - Most im- } \\
\text { portant } \\
\text { partner- } \\
\text { ships }\end{array}$ & $\begin{array}{l}\text { [Wilhelm, } \\
\text { Dolfsma, } \\
\text { 2018; Ili et } \\
\text { al., 2010; } \\
\text { Mortara, } \\
\text { Minshall, } \\
\text { 2011; Lewin } \\
\text { et al., 2017; } \\
\text { Breunig et } \\
\text { al., 2014] }\end{array}$ & $\begin{array}{l}\text { - } \begin{array}{l}\text { Likert } \\
(1-5)\end{array} \\
\text { - } \begin{array}{l}\text { Likert } \\
(1-6)\end{array} \\
\text { - } \begin{array}{l}\text { Likert } \\
(1-5)\end{array}\end{array}$ & $\begin{array}{l}\text { - } \mathrm{F} 1-\mathrm{F} 4 \\
\text { - } \mathrm{B} 1, \mathrm{~B} 2, \\
\mathrm{~B} 6 \\
\text { - } \mathrm{B} 4, \mathrm{~B} 5, \\
\text { B7, D3 }\end{array}$ \\
\hline $\begin{array}{c}\text { PDP } \\
\text { Aspects }\end{array}$ & $\begin{array}{l}\text { - } \begin{array}{l}\text { Degree of } \\
\text { innovation }\end{array} \\
\text { - Adoption } \\
\text { of newer } \\
\text { PDP meth- } \\
\text { ods }\end{array}$ & $\begin{array}{l}{[\text { Cooper, }} \\
2015]\end{array}$ & $\begin{array}{l}\text { Likert } \\
(1-6)\end{array}$ & $\begin{array}{l}-\mathrm{C} 1 \\
-\mathrm{C} 2\end{array}$ \\
\hline$\underset{\substack{\text { OI } \\
\text { Risks }}}{\text { Barriers \& }}$ & $\begin{array}{l}\text { - Perceived } \\
\text { barriers } \\
\text { and risks }\end{array}$ & $\begin{array}{l}\text { [Ili et al., } \\
\text { 2010; } \\
\text { Aquilani et } \\
\text { al., 2017; } \\
\text { Monteiro et } \\
\text { al., 2017] } \\
\end{array}$ & $\begin{array}{l}\text { Likert } \\
(1-5)\end{array}$ & - D4 \\
\hline
\end{tabular}

tion of important information or technologies, or even the loss of control of projects that are being conducted in partnerships [Monteiro et al., 2017].

With regard to the 'Product Development Process (PDP)' construct, the main questions try to assess the degree of innovation carried out by the firm (if radical or incremental) in recent years as well as whether the organization has managed to evolve in its PDP process by adopting new practices such as Agile methodologies or rapid prototyping techniques for example [Cooper, 2015].

The main demographic variables measured were 'company' and 'plant/unit' size (A1), 'age of respondents' (G3), 'respondent area of expertise' (G2), and the respondent's 'job title' (G1 and G4).

\section{Survey application}

The prepared research was applied to directors, managers, and engineers who were working in innovation-related departments in the auto industry such as product and project development areas (product engineering, application, and systems engineering) at the time of the research. Other criteria, such as having enrolled in a graduate course or publishing an article in a journal or for a scientific event, were also used to find potential interviewees. In total, 1,032 invitations were sent, of which 342 started the survey. Of this, 140 individual responses were obtained with valid information for statistical treatment, comprising a response level of $13.6 \%$. This low response rate was not considered a cause of non-response bias as the survey was mainly

${ }^{4}$ The project management methodology that uses short development cycles is also called 'sprint.' 
exploratory and, at the same time, had an average response time of approximately 40 minutes, considered relatively high for these types of questionnaire-based surveys [Forza, 2002], which certainly could decrease the response rate.

The survey was sent by e-mail and responses were collected electronically throughout the second half of 2018, with two follow-up phone calls, the first to ensure that people received the questionnaire and, later, the second to remind respondents about the due date. An effort was made for all major automakers with R\&D operations in Brazil to receive the survey. The same effort was made to include a diverse range of suppliers, covering major automaker's auto parts. With only a few exceptions, most questions used a 5-point or 6-point Likert scale, as shown in Table 2, to measure the importance of each research variable according to the experience and/or perception of the respondent in relation to the behavior of their own company.

\section{Sample Characterization}

The first variable evaluated was the level of experience of the interviewees in relation to their working time in the automotive industry. Respondents had an average of 16 years of experience in the sector.The distribution is shown in Figure 2.

Overall, the seniority level of the surveyed sample was considered moderate to high, which is considered a positive aspect given the particularities of the automotive industry and the fact that obtaining answers from knowledgeable interviewees about the industry reduces random and bias error [Forza, 2002]. In addition, most respondents answered that their companies have a high concentration of their revenue coming from the automotive sector, as per Figure 4, and with considerable Research and Development (R\&D) units located in Brazil by the time the survey was done, as demonstrated by Figure 3 .

As is shown in Figure 5, the sample of interviewees was evenly distributed between automakers and suppliers, so that close to $50 \%$ of respondents came from automotive manufactures and the other $50 \%$ was split between auto parts, assembled sub-system suppliers, and service providers. Another important piece of information about the sample is that around half of the respondents came from companies with at least 1,000 employees working full-time at the time of the survey. Between $25 \%$ and $30 \%$ respondents came from companies with between 100 and 1,000 full-time employees, which shows the predominance of large and mediumsized companies, as shown in Figure 6.

It is worth mentioning that the survey was carried out in 2018 but reflects information from 2015 through 2017, years during which the automotive industry in Brazil was still recovering from a serious economic crisis that hit Brazil and the whole auto sector in 2014 with a $13.6 \%$ drop in light vehicle production in that year alone [Amorim, 2014]. Figure 8 shows that the

\section{Figure 2. Experience in the Automotive} Industry (years)

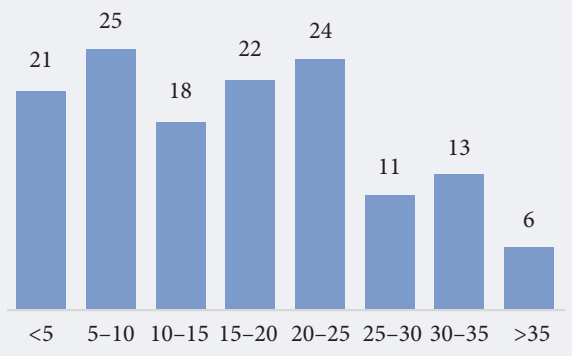

Source: authors.

\section{Figure 3. R\&D Operations in Brazil (shares of responses, \%)}

Does your company have R\&D operations in Brazil?

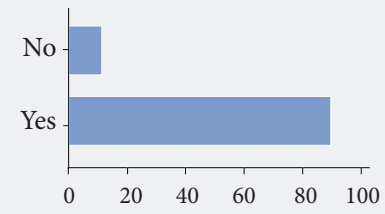

Source: authors.

\section{Figure 4. Business Concentration (shares of responses, \%)}

How much the automotive sector represents of your total sales?

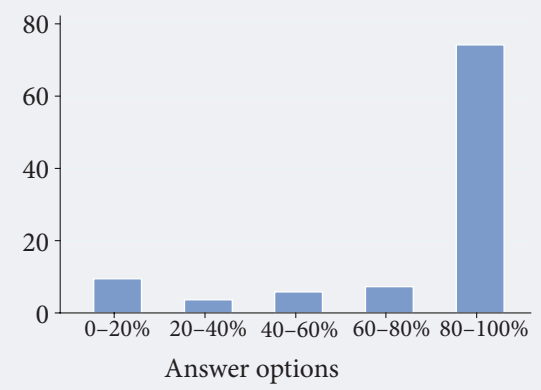

Source: authors.

Figure 5. Position in the Supply Chain (shares of responses, \%)

What is your company supplying in the auto sector?

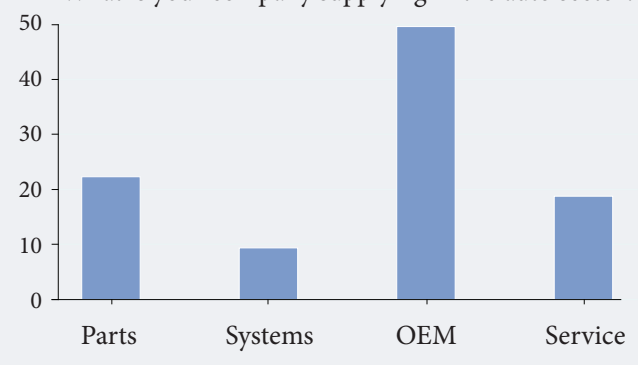

Source: authors. 
companies of the majority of respondents had a significant reduction in the number of active customers in the years prior to the time of the survey. Figure 7 also shows that the majority of companies interviewed also experienced a significant reduction in their revenue streams.

\section{Descriptive Analysis \\ of the Main Research Constructs \\ 'OI organizational culture'}

After the sample characterization, the first construct to be analyzed was the 'OI organizational culture'. In this construct, the survey tries to identify the existence of OI practices among the companies that were analyzed and the maturity and importance of these practices for overall corporate strategy. As described in Figure 9, nearly $80 \%$ of respondents stated that their companies knew and had OI practices in place for at least two years. Close to $45 \%$ had these practices in place for more than five years and more than $30 \%$ had them for more than 10 years. Under 5\% stated that OI practices had ceased being used at their companies.

With regard to the perception of the maturity of OI practices, the survey results showed, as demonstrated in Figure 10, that close to 30\% of the interviewees said OI was an 'essential' part of their innovation process, with targets, tools, and methods well established and aligned with the strategic plan of their companies. Another $30 \%$ said it was in the 'development stage' meaning it was being actively promoted within their companies but not yet truly consolidated. However, near $40 \%$ stated that the OI was still in the introductory phase with only a few experiments, but not yet formally incorporated into the innovation process.

Also, an important variable measured within this survey was the importance that OI had within the strategic innovation plan of the companies that responded to the survey. As shown in Figure 11, for both automakers and suppliers, OI practices were considered important or very important to their company's innovation strategies for nearly $70 \%$ of the respondents. An interesting point of the research is that, counterintuitively, there was a small advantage for suppliers in relation to the degree of importance that OI practices had when compared to automakers, as demonstrated in Figure 11.

Another important observation that can be drawn from the results of this survey, is to determine in which innovation paradigm the Brazilian automotive industry fits best. According to [Chesbrough, 2003] there are two possible paradigms: 'Open Innovation' versus 'Closed Innovation'. To determine the status of a company or industry sector in relation to these paradigms, an analysis should be performed on six different criteria: attitude regarding research, field of expertise, function of one's own R\&D, intellectual property, market ambition, and sources for ideas. From the survey's results, presented in Figure 12, it becomes clear that
Figure 6. Number of Full-time Employees (shares of responses, \%)

How many full-time employees worked at your plant / unit in 2016?

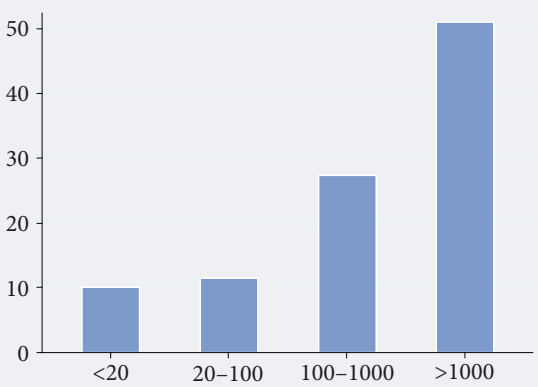

Source: authors.

\section{Figure 7. Revenues Reduction (shares of responses, \%)}

Does your company revenue reduced in the last two years?

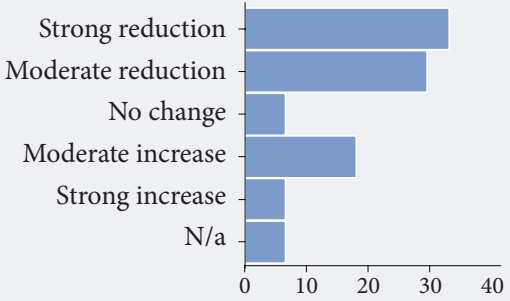

Source: authors

\section{Figure 8. Customer Reduction} (shares of responses, \%)

Did your customer base change in the last two years?

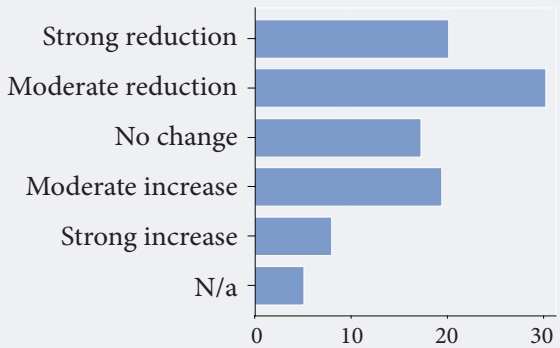

Source: authors.

\section{Figure 9. OI Practice Longevity (shares of responses, \%)}

How long does your company's unit practice OI?

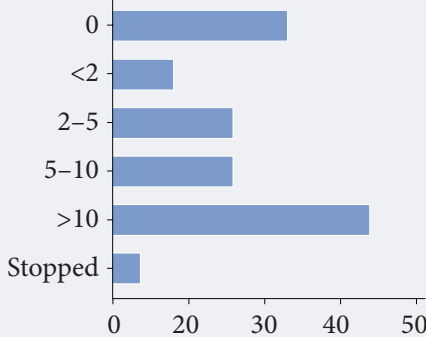

Source: authors. 


\section{Figure 10. Perception of OI Maturity (shares of responses, \%)}

How mature is your company's unit in relation to OI practices?

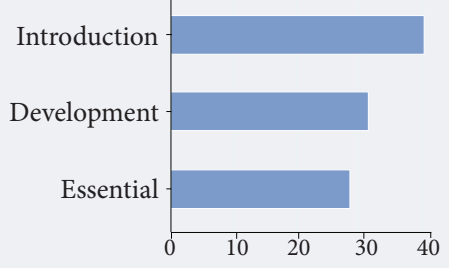

Source: authors.

\section{Figure 11. Importance of OI in Innovation} Strategies (shares of responses, \%)

How important is OI in your company's innovation strategy?
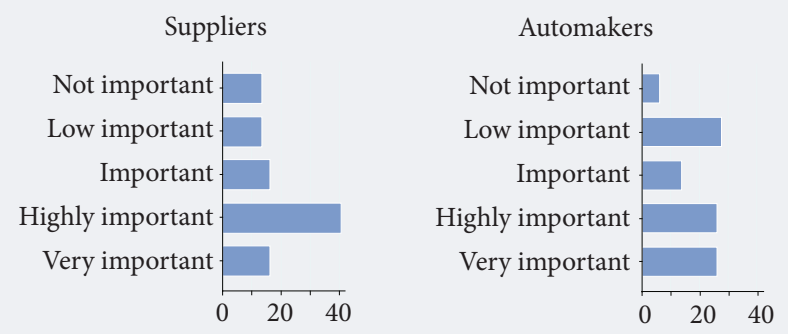

Source: authors.

Figure 12. Contrasting Principles of Closed and Open Innovation (shares of responses, \%)

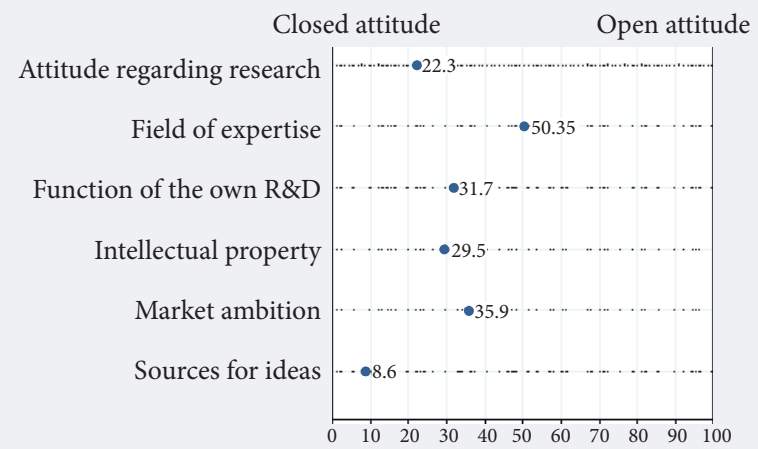

Source: authors.

\section{Figure 13. External Sources for Collaboration} (shares of responses, \%)

What is your preferred external source?

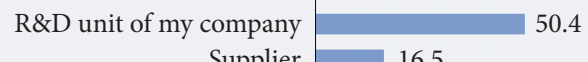

\begin{tabular}{|c|c|}
\hline . & \\
\hline Supplier & \begin{tabular}{|l}
16.5 \\
\end{tabular} \\
\hline Customer & \begin{tabular}{|l|l|} 
& 10.1 \\
\end{tabular} \\
\hline Another unit of my company & 10.1 \\
\hline University & 5.0 \\
\hline Private $R \& D$ institute & 3.6 \\
\hline An industry association & 2.2 \\
\hline Company from a different sector & 0.7 \\
\hline Competitor & 0.7 \\
\hline Public R\&D institute & 0.7 \\
\hline & $\begin{array}{llllll}0 & 10 & 20 & 30 & 1 & 1\end{array}$ \\
\hline
\end{tabular}

Source: authors. the auto industry in Brazil has difficulties in opening and collaborating, given the tendency of the interviewees toward the closed innovation paradigm. A similar analysis was performed by Albers and Miller (2010) on the German auto industry [Albers, Miller, 2010] with analogous results.

As for the preferred external sources used by the automotive industry in Brazil, as depicted in Figure 13, it becomes evident that there is also a preference expressed by respondents for using other $\mathrm{R} \& \mathrm{D}$ units of the same company as well as direct suppliers or customers as possible partners for collaboration when starting new projects. Public R\&D institutes and competitors are rarely cited by the interviewees. Universities are cited by only $5 \%$ of the respondents, also showing low integration and collaboration between the private and public sectors.

As for preferred 'outside-in' initiatives, according to Figure 14, most respondents answered that their companies used internal collaborative intelligence tools to capture information from beyond the frontiers of their respective companies (external environment). This would include benchmarking in multi-functional teams to interpret the market and suggest new products, for example. Informal networks also rank high, which is in line with previous literature that already shows these types of linkages to be common, mainly among people that work in geographic proximity, for example, in the same regional industry cluster [Dahl, Pedersen, 2004].

Also, in Figure 14, the acquisition of R\&D services and co-design/co-engineering were reasonably cited. This type of initiative is very common among customer-supplier partnerships or vice-versa, something that happens within the automotive industry when a vehicle manufacturer establishes a partnership with a supplier of combustion engines for the specific development of a new engine, for example. Once again, research grants for universities appear at the bottom of the graph showing that companies are less interested in this type of initiative as well as the acquisition of new companies. Monitoring the competition is the third most cited outside-in initiative as most automo-

Figure 14. Main Outside-In Initiatives (shares of responses, \%)

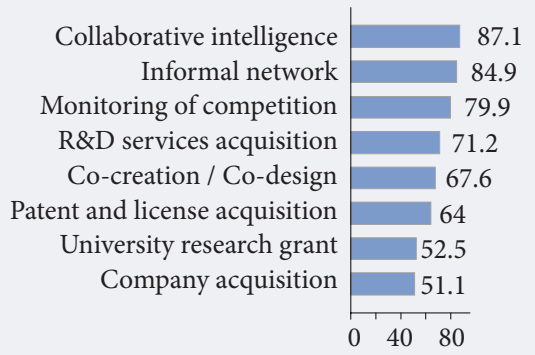

Source: authors. 


\section{Figure 15. Main Inside-Out Initiatives} (shares of responses, \%)

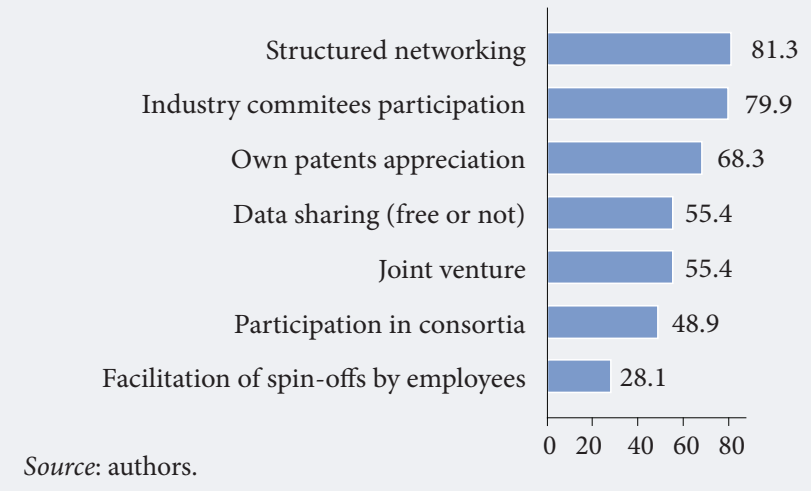

tive companies have their own programs to check on the performance of their competitor's products, such as the 'tear-down' initiative very common among automakers in which they acquire competitors' vehicles on the market, bring them to their engineering labs and then dismantle the cars to check components and technological features in order to improve their own products or establish some advantage. After analyzing the results of this section of the research, it is also clear that, although there are many initiatives from the inside out, they are uncoordinated and do not show a clear path that goes out from within company boundaries, leading to the external environment, outside the borders of the company.

As for the preferred 'inside out' initiatives, according to Figure 15, most respondents pointed to the structured network as the main initiative, along with par- ticipation on industry committees for standardization. The structured network usually involves sharing knowledge at industry meetings, forums, on social media, and at congresses. Standardization committees are more concerned with creating best practices and the normalization of the sector's practices. Those are, once again, typical inside-out initiatives from industries or companies that still have a closed mindset. There is not yet an active mindset for exploiting their own discoveries and spin-offs. Such initiatives were rarely mentioned among respondents, which, again, shows that there is still a strong tendency to keep everything inside companies.

In general, the initiatives that are highlighted in this part of the research, in Figure 13, Figure 14, and Figure 15, point to an environment known as 'me-tooinnovation' [Ili et al., 2010], i.e., they do not lead companies and industries to innovations considered more radical or disruptive, staying too much in the 'same old same old' incremental process of improving their own existing products. This is a scenario in which limited collaboration prevails and where industrial clusters are unable to evolve into a broader ecosystem of innovation.

\section{'PDP aspects'}

When it comes to PDP, the research yielded two relevant contributions. The first relevant contribution is the fact that it shows that 'PDP improvements' are one of the major reasons for companies in the auto sector to establish partnerships, even if, as already demonstrated, this is done within their close circle of partners, such as customers and direct suppliers. When the in-

\section{Figure 16. Main Reasons Why Companies Collaborate (shares of responses, \%)}

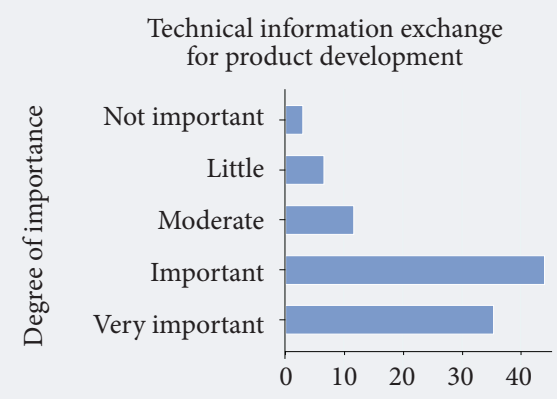

Access to new infrastructure

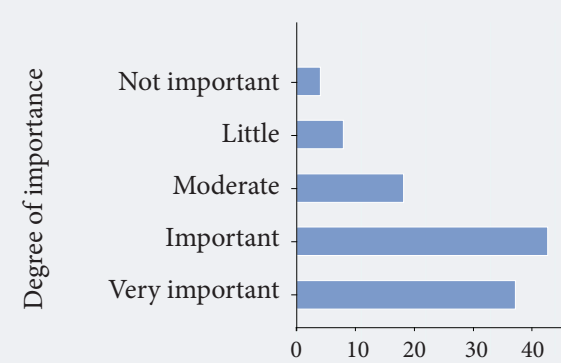

Time and cost reduction for product development

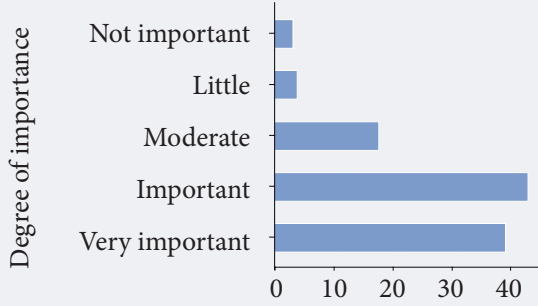

Access to new R\&D skills

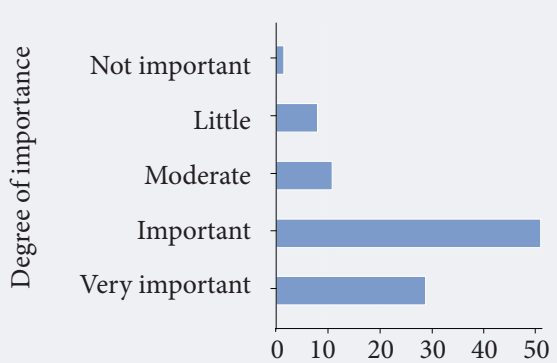

Source: authors. 
Figure 17. PDP Evolution

(shares of responses, \%)

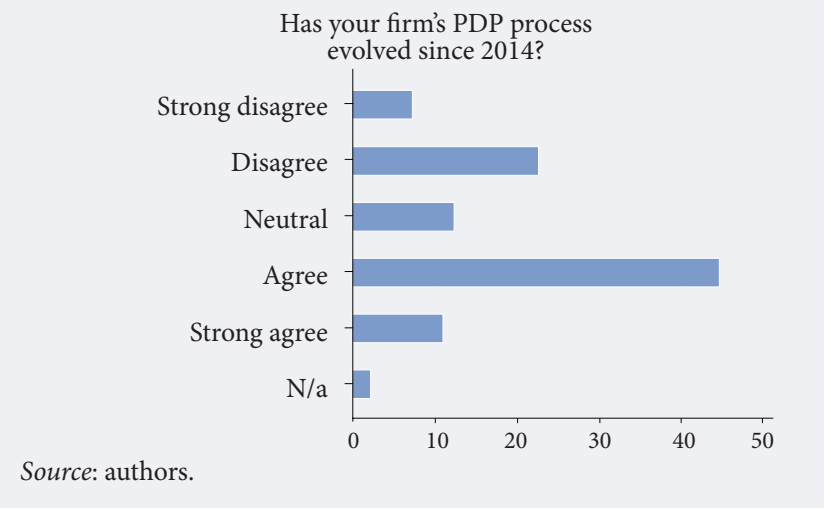

terviewees are asked about the main reasons that motivated their partnerships, the answers with the greatest statistical representation were, according to what is presented in Figure 16: (1) obtain or exchange technical knowledge, (2) access to infrastructure (laboratories and equipment for example), (3) access to new $\mathrm{R} \& \mathrm{D}$ processes and, lastly, (4) the reduction of the time and cost for the development of new products.

The second relevant contribution is that, even though the interviewees responded that the PDPs of their companies have evolved since 2014 (as shown in Figure 17), the products developed by these processes have not changed significantly, i.e., the PDPs still largely focus on the development of incremental products as shown in Figure 18.

\section{'OI barriers and risks'}

When asked about the reasons or reasons why OI did not progress within their respective companies, there were several reasons cited by the respondents as shown in Figure 19.

\section{Figure 19. Main Barriers that Hinder OI (shares of responses, \%)}

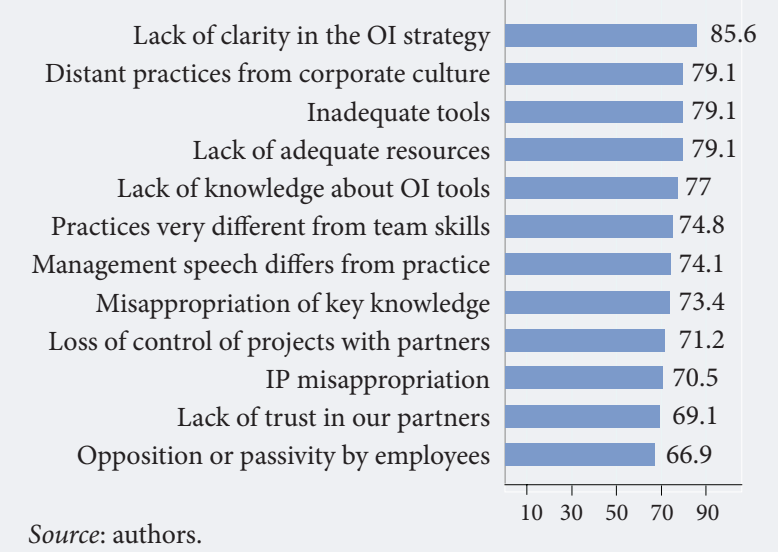

\section{Figure 18. Type of PDP Projects (shares of}

responses, \%)

Products developed are based on information from previous designs?

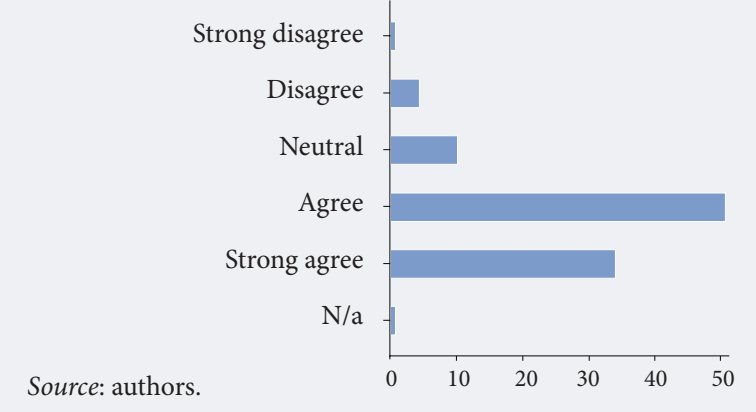

In general, all the reasons were very well scored by the respondents, with special emphasis on the reason "Lack of Clarity in the OI strategy". In the sequence, other motivations appear strongly connected with ignorance concerning how OI works and a lack of clarity about management's discourse. There is still a latent fear within organizations to open and lose control of projects that are done in partnerships or even a lack of trust in their partners. Finally, there is still the passivity on the part of employees who, in a way, do not pull the initiatives forward by demanding and asking for them to become mainstream within their companies. All these reasons make the lack of a clear strategy for OI evident within the interviewed companies and, in a way, portrays the situation of the automotive sector in Brazil and, possibly, elsewhere.

\section{Regression Analysis for OI Practices}

To confirm reliability of the research, a statistical regression was performed to verify whether, within the selected sample of respondents, the hypothesis that companies that have a culture that favors the practice of OI perceive a positive effect on their innovation results, which in this research directly translates into improvements in the PDP construct. The practice of OI and its positive impact upon the companies' PDP process, whether improving the current process or leveraging innovations, is something widely explored and consolidated in the literature and therefore, should be confirmed by the results of the statistical regression analysis of the conceptual model in Figure 20 to bring reliability to the survey results.

These hypotheses are then tested using a measure-bymeasure analysis. The complete set of hypotheses are summarized in the Table 3.

The measures presented in Table 3 were subjected to rotated principal-component factor (PCF) analyses to reduce and identify the relevant factors for each measure. Orthogonal rotations (varimax) were performed using Stata/IC13 software. The criteria chosen for adopting or discarding factors was based on a mini- 
Figure 20. Conceptual Model

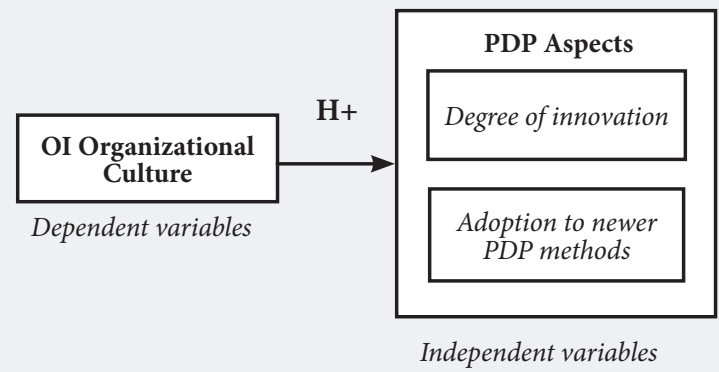

Source: authors.

mum eigenvalue of 1.0, with a minimum Cronbach's alpha of 0.6. Variables with a factor loading of less than 0.5 were purged and the analysis was iteratively rerun. A Kaiser-Meyer-Olkin (KMO) test was also used to assess the sampling adequacy for each measure in the model, with a minimum threshold of 0.5 .

Organizational culture was assessed by asking respondents, on the same scale, to assess characteristics of management and employees that can improve the adoption of open innovation systems (i.e., the company has an environment that favors open innovation practices). For this group of questions (Table 4), two factors with an eigenvalue greater than 1 were found. The first factor, 'Cult_Aspects_F1' ( = 3.55), explains $39 \%$ of the variance with a Cronbach-alpha of 0.87 . The second factor, 'Cult_Aspects_F2' $(\lambda=2.58)$ explains $29 \%$ of the variance with an alpha of 0.80 . Both factors are kept in the analysis.

Two additional variables, 'OI_Maturity' and 'OI_Strategy', assessed the respondents' perception of how ma-

\section{Table 3. Hypotheses for the Regression Model}

\begin{tabular}{|c|c|c|}
\hline $\begin{array}{l}\text { Hypo- } \\
\text { thesis }\end{array}$ & $\begin{array}{l}\text { Dependent } \\
\text { measure }\end{array}$ & Independent measure \\
\hline \multirow{3}{*}{ H1 } & \multirow{5}{*}{$\begin{array}{l}\text { - Cultural } \\
\text { aspects } \\
\text { (regarding OI } \\
\text { practices) } \\
\text { - Survey } \\
\text { questions: } \\
\text { B4, B5, B7 } \\
\text { and D3 } \\
\text { - Question's } \\
\text { scale: Likert } \\
1-5\end{array}$} & $\begin{array}{l}\text { Degree of innovation } \\
\text { (incremental/radical) }\end{array}$ \\
\hline & & - Survey question: C1 \\
\hline & & - Question's scale: Likert 1-5 \\
\hline \multirow[b]{2}{*}{$\mathrm{H} 2$} & & $\begin{array}{l}\text { Adoption to newer PDP methods/ } \\
\text { models }\end{array}$ \\
\hline & & - Survey question: C2 \\
\hline & & \\
\hline
\end{tabular}

ture the company is with regard to open innovation practices and how integrated into its strategy open innovation is, respectively. Since each of these variables correspond to a single question in the survey, they are kept as distinct variables.

For the construct PDP Aspects, both questions use a five-point Likert scale (from completely disagree to completely agree). The first asks respondents to assess how incremental or radical the innovations performed by their company are, the second measure assesses whether the processes related to product development have changed in the last few years (since 2014) and whether new methods and tools have been adopted.

For the degree of innovation measure (Table 5), two factors with an eigenvalue greater than 1.0 were found. 'PDP_Degree_F1' $(\lambda=1.51)$ presented a Cronbach-alpha of 0.67 and remained in the analysis. Even though the other factor presented a sufficient eigenvalue, its Cronbach-alpha was 0.58 and was discarded from the analysis.

\section{Table 4. Organizational Culture in OI Factor Analysis}

\begin{tabular}{|l|l|l|}
\hline \multicolumn{1}{|c|}{ Degree of innovation performed in their company } & \multicolumn{1}{|c|}{$\begin{array}{c}\text { Factor 1 } \\
\text { (PDP } \\
\text { adoption) }\end{array}$} & $\begin{array}{c}\lambda \text { Factor 2 } \\
\text { (discarded) }\end{array}$ \\
\hline Management encourages teamwork & 0.89 & - \\
\hline Management encourages everyone's participation in the search for solutions & 0.87 & - \\
\hline Leaders or managers in your plant/unit have the flexibility needed to implement changes & 0.57 & - \\
\hline Employees' suggestions for improvement are encouraged & 0.73 & - \\
\hline Employees that propose improvements are recognized for their solutions & 0.61 & - \\
\hline The company offers training to its employees & 0.68 & - \\
\hline The company uses techniques to stimulate creativity among its employees & - & 0.69 \\
\hline $\begin{array}{l}\text { A team (dedicated or not) is in charge of promoting a culture of open innovation within the more general } \\
\text { corporate culture }\end{array}$ & - & 0.81 \\
\hline Indicators specific to open innovation are used & - & 0.88 \\
\hline$\%$ prop. & - & 0.29 \\
\hline \% cumul. & 0.39 & 0.68 \\
\hline Eigenvalue & 0.39 \\
\hline Cronbach-alpha & 3.55 & 2.58 \\
\hline KMO & 0.87 & 0.80 \\
\hline Source: authors. & 0.81 & \\
\hline
\end{tabular}




\section{Table 5. Degree of Innovation Performed in their Company Factor Analysis}

Degree of innovation performed in their company

The products developed are more incremental than radical in their innovations

The products are developed based on information from prior projects / products

Products are being developed to new target markets

The products developed necessitated the development of a new platform and / or new business models

$\%$ prop.

$\%$ cumul.

Eigenvalue

Cronbach-alpha

KMO

\begin{tabular}{|l|l|}
\hline $\begin{array}{c}\text { Factor 1 } \\
\text { (PDP } \\
\text { adoption) }\end{array}$ & $\begin{array}{c}\text { Factor 2 } \\
\text { (discarded) }\end{array}$ \\
\hline 0.86 & - \\
\hline 0.87 & - \\
\hline- & 0.84 \\
\hline- & 0.83 \\
\hline 0.38 & 0.36 \\
\hline 0.38 & 0.73 \\
\hline 1.51 & 1.42 \\
\hline 0.67 & $\mathbf{0 . 5 8}$ \\
\hline 0.59 & \\
\hline &
\end{tabular}

Source: authors.

\section{Table 6. Adoption of Newer PDP Methods and Tools}

\begin{tabular}{|l|l|}
\hline \multicolumn{1}{|c|}{ Adoption to newer PDP methods and tools } & \multicolumn{1}{c|}{\begin{tabular}{c} 
Factor $\mathbf{1}_{\text {(PDP }}$ adoption) \\
\hline The way PDP is done has changed since 2014
\end{tabular}} \\
\hline Open innovation has influenced the way PDP is done & 0.70 \\
\hline $\begin{array}{l}\text { Open innovation is responsible for the improvement of existing and implemented PDPmethods or tools in } \\
\text { your plant / unit }\end{array}$ & 0.94 \\
\hline $\begin{array}{l}\text { Open innovation is responsible for the adoption of new PDP methods or tools (scrum, agile, etc.) in your } \\
\text { plant / unit }\end{array}$ & 0.96 \\
\hline \% prop. & 0.91 \\
\hline \% cumul. & 0.78 \\
\hline Eigenvalue & 0.78 \\
\hline Cronbach-alpha & 3.12 \\
\hline KMO & 0.90 \\
\hline Source: authors. & 0.80 \\
\hline
\end{tabular}

\section{Table 7. OLS Regression Correlations for H1 \& H2: OI Organizational Culture versus PDP Aspects}

\begin{tabular}{|c|c|c|c|}
\hline \multirow[b]{2}{*}{ Measure } & \multirow{2}{*}{$\begin{array}{l}\text { Dependent } \\
\text { Variable }\end{array}$} & \multicolumn{2}{|c|}{ Independent Variable } \\
\hline & & $\begin{array}{l}\text { PDP } \\
\text { Degree }\end{array}$ & $\begin{array}{l}\text { PDP } \\
\text { Adoption }\end{array}$ \\
\hline \multirow{4}{*}{$\begin{array}{l}\text { Cultural } \\
\text { aspects }\end{array}$} & Cult_Aspects_F1 & 0.11 & $0.35^{\star * *}$ \\
\hline & Cult_Aspects_F2 & -0.06 & $0.35^{\star * *}$ \\
\hline & OI_Strategy & 0.13 & $0.60^{* * *}$ \\
\hline & OI_Maturity & $0.21^{\star}$ & $0.19^{*}$ \\
\hline \multicolumn{4}{|c|}{$\begin{array}{l}\text { Note: } \mathrm{p} \text {-values: }+\mathrm{p}<0.1,{ }^{*} \mathrm{p}<0.05,{ }^{* *} \mathrm{p}<0.01,{ }^{* *} \mathrm{p}<0.001 \text { (highlighted in } \\
\text { bold). } \\
\text { Source: authors. }\end{array}$} \\
\hline
\end{tabular}

\section{Table 8. Hypothesis Test Results}

\begin{tabular}{|c|c|c|}
\hline Hypothesis & Independent measure & Hypothesis test results \\
\hline H1 & $\begin{array}{l}\text { - Degree of innovation } \\
\text { (incremental / radical) }\end{array}$ & Partially Accepted \\
\hline H2 & $\begin{array}{l}\text { - Adoption to newer } \\
\text { PDP methods/models }\end{array}$ & Accepted \\
\hline
\end{tabular}

Note: Dependent variable - Cultural aspects (regarding OI practices). Source: authors.
Finally, for the measure of adoption of newer PDP methods and tools (Table 6), only one factor remained, 'PDP_adoption' $(\lambda=3.12)$, explaining $78 \%$ of the variance found. With a Cronbach-alpha of 0.9 and KMO of 0.8 , it was kept in the analysis.

\section{Regression analysis}

After a correlation matrix was performed with the variables created for the regression and no significant correlation was observed between the same group of measures, the next step was to move on to the regression. Ordinary Least Squares (OLS) regressions were performed using Stata/IC13 software. All variables created were considered in the analysis as well as the respondent's origin (as in, from an automaker or supplier) is used as a control variable. Variables in the regression that resulted in a significant p-value, which is taken to be less than 0.1 in this exploratory analysis, are highlighted in bold in Table 7 .

The results of the hypothesis testing from the conceptual model presented in Figure 19 is found in Table 8.

Hypotheses $\mathrm{H} 1$ and $\mathrm{H} 2$ concern the measure of 'Cultural Aspects' to the 'Degree of Innovation' and 'Adoption of newer PDP methods', respectively. The cultural aspects measure asks respondents to assess changes 
in open innovation culture that their company might have experienced in the past few years, as well as asking respondents to assess characteristics of management and employees that can improve the adoption of open innovation engagements (i.e. the company has an environment that favors open innovation practices).The results suggest a positive relationship between having a corporate culture that favors open innovation practices and evolving their PDP to adopt newer methodologies, as well as having a greater focus on radical innovation, which confirms the previous theory about OI and, thus, brings reliability to our study.

\section{Conclusion}

This is descriptive research that aims to show evidence that the automotive industry in Brazil does not display a collaboration pattern typical of an innovation ecosystem that usually involves a wide range of actors such as competitors, government agencies, universities, private and public research entities, among others. This has been accomplished by conducting a questionnaire-based survey to gain insights into the three main constructs that are widely discussed in the literature about OI and ecosystems of innovation and can serve as indicators to show whether a particular company or industrial sector is entering a broader ecosystem of collaboration or not. The first construct is the organizational culture around $\mathrm{OI}$ and, observing the research results, although the automotive industry in Brazil knows and values OI and has implemented some of its practices, it still has a 'closed attitude', because it relies heavily on its own resources, such as $R \& D$, to develop new products, new technologies, and explore new ideas. Besides, the survey results showed that most of the new partnerships implemented are between close partners, such as direct suppliers and customers, and have not yet extended to more distant actors, such as competitors, universities and other public and or private research agencies. Also, the initiatives are still very much focused on the 'outside-in' direction, based essentially on collaborative intelligence and informal networking. As for IP, research has shown that it has not yet been properly explored in both, the 'inside-out' and the 'outside-in', directions.

Another important contribution brought by this research is the fact that it shows that the main reason why participants in the automotive industry establish new partnerships is to improve their PDP, whether by providing access to new technical information/skills or by providing access to new R\&D infrastructures. In addition, research has shown that while the PDPs have improved over time, new products developed by these processes are still primarily of an incremental nature. As for the main barriers that prevent OI from progressing and evolving, the results of the research show that, in most cases, the main roadblocks are usually related to a lack of clarity in the OI implementation strategy, inadequate tools/resources or a lack of knowledge about the proper use of tools/resources, a gap between the company culture and the culture of OI, among others. The results point to the existence of a latent fear in organizations to open and lose control of projects carried out as part of partnerships or even a lack of trust in their partners when working in collaboration agreements.

Finally, a regression analysis was conducted to confirm the hypothesis that companies that have a more collaborative attitude (by practicing OI for example) obtain better results in their PDPs, either through the evolution of the methods that are used or by improving the level of innovation of the products that are developed. The results obtained through the regression test demonstrated a positive effect of this relationship, confirming the previous existing theory and giving validity to this research.

The results of this research demonstrate the need for public authorities and private entities to act together in the formulation of public policies to support historical and traditional actors in their process of evolution and integration into an innovation ecosystem whether they are still in a nascent or emerging phase. If no adaptation or strategy change is adopted by such players and no public support policy implemented, there is a risk that these large players will not be able to penetrate the entry barrier of these innovation ecosystems, losing the leadership of their markets, and becoming only marginal players, if they do not collapse before.

The authors thank the Automotive Engineering Center (AEC) of the Escola Politécnica (Engineering School) of the University of São Paulo (Poli-USP) for the support provided to develop and apply the questionnaire-based survey to the automotive industry in Brazil.

\section{References}

Adner R. (2006) Match your innovation strategy to your innovation ecosystem. Harvard Business Review, April. https://hbr.org/2006/04/ match-your-innovation-strategy-to-your-innovation-ecosystem, accessed 18.02.2021.

Adner R., Kapoor R. (2010) Value creation in innovation ecosystems: How the structure of technological interdependence affects firm performance in new technology generations. Strategic Management Journal, 31 (3), 306-333, https://doi.org/10.1002/smj.821

Aquilani B., Abbate T., Codini A. (2017) Overcoming cultural barriers in open innovation processes through intermediaries: A theoretical framework. Knowledge Management Research and Practice, 15(3), 447-459. https://doi.org/10.1057/s41275-017-0067-5

Armellini F., Kaminski P.C., Beaudry C. (2011) Consortium for research and innovation in aerospace in Quebec, Canada a reference model for the Brazilian aerospace industry. Product Management \& Development, 9(2), 101-109. DOI: 10.4322/pmd.2012.002.

Autio E., Thomas L.D.W. (2014) Innovation ecosystems: Implications for innovation management. In: Oxford Handbook of Innovation Management (eds. M. Dodgson, D.M. Gann, N. Phillips), Oxford: Oxford University Press, pp. 204-228. DOI: 10.1093/oxford$\mathrm{hb} / 9780199694945.013 .012$.

Balland P.A., Boschma R., Frenken K. (2015) Proximity and Innovation: From Statics to Dynamics. Regional Studies, 49(6), 907-920. https:// doi.org/10.1080/00343404.2014.883598 
Banister D. (2007) Cities, mobility and climate change. Journal of Industrial Ecology, 11(2), 7-10. https://doi.org/10.1162/jie.2007.1271

Baptista R., Swann P. (1998) Do firms in clusters innovate more? Research Policy, 27(5), 525-540. https://doi.org/10.1016/S00487333(98)00065-1

Bathelty H., Cohendet P. (2014) The creation of knowledge: Local building, global accessing and economic development-toward an agenda. Journal of Economic Geography, 14(5), 1-14. https://doi.org/10.1093/jeg/lbu027

Beadry C., Swann P. (2001) Growth in Industrial Clusters: A Bird's Eye View of the United Kingdom, Stanford, CA: Stanford Institute for Economic Policy Research.

Beaudry C. (2001) Entry, growth and patenting in industrial clusters: A study of the aerospace industry in the UK. International Journal of the Economics of Business, 8(3), 405-436. https://doi.org/10.1080/13571510110079000

Beaudry C., Breschi S. (2003) Are firms in clusters really more innovative? Economics of Innovation and New Technology, 12(4), 325-342, https://doi.org/10.1080/10438590290020197

Beirao G., Sarsfield Cabral J.A. (2007) Understanding attitudes towards public transport and private car: A qualitative study. Transport Policy, 14(6), 478-489. https://doi.org/10.1016/j.tranpol.2007.04.009

Bell G.G. (2005) Clusters, networks, and firm innovativeness. Strategic Management Journal, 26(3), 287-295. https://doi.org/10.1002/ smj.448.

Bellini F., Dulskaia I., Savastano M., D’Ascenzo F. (2019) Business Models Innovation for Sustainable Urban Mobility in Small and MediumSized European Cities. Management and Marketing, 14(3), 266-277. DOI:10.2478/mmcks-2019-0019

Benitez G.B., Ayala N.F., Frank A.G. (2020) Industry 4.0 innovation ecosystems: An evolutionary perspective on value cocreation. International Journal of Production Economics, 228, 107735 https://doi.org/10.1016/j.ijpe.2020.107735.

Bianchi M., Cavaliere A., Chiaroni D., Frattini F., Chiesa V. (2011) Organisational modes for Open Innovation in the bio-pharmaceutical industry: An exploratory analysis. Technovation, 31(1), 22-33 https://doi.org/10.1016/j.technovation.2010.03.002

Bigliardi B., Dormio A.I., Galati F. (2012) The adoption of open innovation within the telecommunication industry. European Journal of Innovation Management, 15(1), 27-54. https://doi.org/10.1108/14601061211192825

Bogers M., Zobel A.K., Afuah A., Almirall E., Brunswicker S., Dahlander L., Frederiksen L., Gawer A., Gruber M., Haefliger S., Hagedoorn J., Hilgers D., Laursen K., Magnusson M.G., Majchrzak A., McCarthy I.P., Moeslein R.M., Nambisan S., Piller F.T., Radziwon A., RossiLamastra C., Sims J., Ter Wal A.L.J. (2017) The open innovation research landscape: Established perspectives and emerging themes across different levels of analysis. Industry and Innovation, 24(1), 8-40. https://doi.org/10.1080/13662716.2016.1240068

Breunig K.J., Aas T.H., Hydle K.M. (2014) Incentives and performance measures for open innovation practices. Measuring Business Excellence, 18(1), 45-54. https://doi.org/10.1108/MBE-10-2013-0049

Broekel T., Boschma R. (2012) Knowledge networks in the Dutch aviation industry: The proximity paradox. Journal of Economic Geography, 12(2), 409-433. https://doi.org/10.1093/jeg/lbr010

Burns L.D. (2013) A vision of our transport future. Nature, 497, 181-182. https://doi.org/10.1038/497181a

Carayannis E.G., Campbell D.F.J. (2009) 'Mode 3' and 'Quadruple Helix': Toward a 21st century fractal innovation ecosystem. International Journal of Technology Management, 46(3-4). DOI: 10.1504/ijtm.2009.023374.

Chesbrough H.W. (2003) Open Innovation. The new imperative for creating and profiting from technology, Cambridge, MA: Harvard Business Publishing.

Chesbrough H.W., Appleyard M.M. (2007) Open innovation and strategy. California Management Review, 50(1), 57-76. https://doi. org/10.2307\%2F41166416.

Chong Z.J., Qin B., Bandyopadhyay T., Wongpiromsarn T., Rankin E.S., Ang M.H., Frazzoli E., Rus D., Hsu D., Low K.H. (2011) Autonomous personal vehicle for the first-and last-mile transportation services. Paper presented at the 2011 IEEE 5th International Conference on Cybernetics and Intelligent Systems (CIS) 17-19 September 2011, Qingdao, China. DOI: 10.1109/ICCIS.2011.6070337.

CooperR.G.(2015)What'sNext?:AfterStage-Gate.Research-TechnologyManagement,57(1),20-31.https://doi.org/10.5437/08956308X5606963

Dahl M.S., Pedersen C.Ø.R. (2004) Knowledge flows through informal contacts in industrial clusters: Myth or reality? Research Policy, 33(10), 1673-1689. https://doi.org/10.1016/j.respol.2004.10.004

Dahlander L., Gann D.M. (2010) How open is innovation? Research Policy, 39(6), 699-709. https://doi.org/10.1016/j.respol.2010.01.013

Delgado M., Porter M.E., Stern S. (2016) Defining clusters of related industries. Journal of Economic Geography, 16(1), 1-38. https://doi. org/10.1093/jeg/lbv017

Forza C. (2002) Survey research in operations management: A process-based perspective. International Journal of Operations and Production Management, 22(2), 152-194. https://doi.org/10.1108/01443570210414310

Fransman M. (2010) The new ICT ecosystem: Implications for policy and regulation, Cambridge (UK): Cambridge University Press.

Gassmann O., Enkel E. (2004) Towards a theory of Open Innovation: Three core process archetypes. 2004, Paper presented at the R\&D Management Conference, January 2004. https://www.researchgate.net/publication/36384702_Towards_a_Theory_of_Open_Innovation_ Three_Core_Process_Archetypes, accessed 20.07.2021.

Gawer A., Cusumano M.A. (2014) Industry platforms and ecosystem innovation. Journal of Product Innovation Management, 31(3), 417433. https://doi.org/10.1111/jpim.12105

Gomes L.A., Facin A.L.F., Salerno M.S., Ikenami R.K. (2018) Unpacking the innovation ecosystem construct: Evolution, gaps and trends. Technological Forecasting and Social Change, 136(11), 30-48. https://doi.org/10.1016/j.techfore.2016.11.009

Graham-Rowe E., Skippon S., Gardner B., Abraham C. (2011) Can we reduce car use and, if so, how? A review of available evidence. Transportation Research Part A: Policy and Practice, 45(5), 401-418. https://doi.org/10.1016/j.tra.2011.02.001

Henn S., Bathelt H. (2015) Knowledge generation and field reproduction in temporary clusters and the role of business conferences. Geoforum, 58, 104-113. https://doi.org/10.1016/j.geoforum.2014.10.015

Hering S., Redlich T., Wulfsberg J.P., Bruhns F.-L. (2011) Open innovation in the automotive industry. ZWF Zeitschrift fuer Wirtschaftlichen Fabrikbetrieb, 106(9), 647-652.

Ho C.Q., Hensher D.A., Mulley C., Wong Y.Z. (2018) Potential uptake and willingness-to-pay for Mobility as a Service (MaaS): A stated choice study. Transportation Research Part A: Policy and Practice, 117, 302-318. https://doi.org/10.1016/j.tra.2018.08.025

Humphrey J., Schmitz H. (2002) How does insertion in global value chains affect upgrading in industrial clusters? Regional Studies, 36(9), 1017-1027. https://doi.org/10.1080/0034340022000022198

Iammarino S., McCann P. (2006) The structure and evolution of industrial clusters: Transactions, technology and knowledge spillovers. Research Policy, 35(7), 1018-1036. https://doi.org/10.1016/j.respol.2006.05.004

Iansiti M., Levien R. (2002) The New Operational Dynamics of Business Ecosystems: Implications for Policy, Operations and Technology Strategy (Harvard Business School Working Paper 03-030), Cambridge, MA: Harvard Business School Press. DOI: 10.1523/JNEUROSCI.1166-06.2006.

Iansiti M., Levien R. (2004) Strategy as Ecology. Harvard Business Review, March. https://hbr.org/2004/03/strategy-as-ecology, accessed 18.02.2021.

Ili S., Albers A., Miller S. (2010) Open innovation in the automotive industry. R\&D Management, 40(3), 246-255. https://doi.org/10.1111/ j.1467-9310.2010.00595.x

Jittrapirom P., Caiati V., Feneri A.M., Ebrahimigharehbaghi S., Alonso-Gonzalez M.J., Narayan J. (2017) Mobility as a service: A critical review of definitions, assessments of schemes, and key challenges. Urban Planning, 2(2), 13-25. DOI:10.17645/up.v2i2.931.

Kapoor R., Lee J.M. (2013) Coordinating and competing in ecosystems: How organizational forms shape new technology investments. Strategic Management Journal, 34(3), 274-296. https://oi.org/10.1002/smj.2010 
Karim D.M. (2017) Creating an Innovative Mobility Ecosystem for Urban Planning Areas. In: Disrupting Mobility (eds. G. Meyer, S. Shaheen), Hedelberg, Dordrecht, London, New York: Springer, pp. 21-47. https://doi.org/10.1007/978-3-319-51602-8_2

Koen P.A., Bertels H.M.J., Kleinschmidt E.J. (2014) Managing the front end of innovation-part II: Results from a three-year study. Research Technology Management, May-June, 25-35. https://doi.org/10.5437/08956308X5703199

Lewin A.Y., Valikangas L., Chen J. (2017) Enabling Open Innovation: Lessons from Haier. International Journal of Innovation Studies, 1(1), 5-19. https://doi.org/10.3724/SP.J.1440.101002

Lines T., Monypenny R. (2006) Industrial Clustering: A Literature Review. https://www.researchgate.net/publication/238712690_Industrial_Clustering, accessed 10.07.2021.

Lyons G. (2018) Getting smart about urban mobility - Aligning the paradigms of smart and sustainable. Transportation Research Part A: Policy and Practice, 115, 4-14. https://doi.org/10.1016/j.tra.2016.12.001

Ma Y., Rong K., Mangalagiu D., Thornton T.F., Zhu D. (2018) Co-evolution between urban sustainability and business ecosystem innovation: Evidence from the sharing mobility sector in Shanghai. Journal of Cleaner Production, 188, 942-953. https://doi.org/10.1016/j. jclepro.2018.03.323

Marin R., Kaminski P.C., Armellini F., Bouchardy A. (2018) Open Innovation practices in the automotive industry?: an exploratory comparison between Brazil and France (SAE Technical Paper 2018-36-0210). https://doi.org/10.4271/2018-36-0210.

Monteiro F., Mol M., Birkinshaw J. (2017) Ready to be Open? Explaining the Firm Level Barriers to Benefiting From Openness to External Knowledge. Long Range Planning, 50(2), 282-295. https://doi.org/10.1016/j.lrp.2015.12.008

Moore J.F. (1993) Predators and prey: A new ecology of competition. Harvard Business Review, May-June. https://hbr.org/1993/05/predators-and-prey-a-new-ecology-of-competition, accessed 18.02.2021.

Mortara L., Minshall T. (2011) How do large multinational companies implement open innovation? Technovation, 31(10-11), 586-597. https://doi.org/10.1016/j.technovation.2011.05.002

Ning Z., Xia F., Ullah N., Kong X., Hu X. (2017) Vehicular social networks: Enabling smart mobility. IEEE Communications Magazine, 55(5), 16-55. DOI: 10.1109/MCOM.2017.1600263.

Oberg C., Alexander A.T. (2019) The openness of open innovation in ecosystems - Integrating innovation and management literature on knowledge linkages. Journal of Innovation and Knowledge, 4(4), 211-218. https://doi.org/10.1016/j.jik.2017.10.005

Parmentier G., Mangematin V. (2014) Orchestrating innovation with user communities in the creative industries. Technological Forecasting and Social Change, 83, 40-53. https://doi.org/10.1016/j.techfore.2013.03.007

Poudenx P. (2008) The effect of transportation policies on energy consumption and greenhouse gas emission from urban passenger transportation. Transportation Research Part A: Policy and Practice, 42(6), 901-909. https://doi.org/10.1016/j.tra.2008.01.013

Prettenthaler F.E., Steininger K.W. (1999) From ownership to service use lifestyle: The potential of car sharing. Ecological Economics, 28(3), 443-453. https://doi.org/10.1016/S0921-8009(98)00109-8

Pulkkinen J., Jussila J., Partanen A., Trotskii I., Laiho A. (2019) Smart Mobility: Services, Platforms and Ecosystems. Technology Innovation Management Review, 9(9), 15-24. DOI: 10.22215/timreview/1265.

Rabelo R.J., Bernus P. (2015) A holistic model of building innovation ecosystems. IFAC-Papers OnLine, 48(3), 2250-2257. https://doi. org/10.1016/j.ifacol.2015.06.423

Rajashekara K. (2013) Present status and future trends in electric vehicle propulsion technologies. IEEE Journal of Emerging and Selected Topics in Power Electronics, 1(1), 3-10. DOI: 10.1109/JESTPE.2013.2259614

Rohrbeck R., Holzle K., Gemunden H.G. (2009) Opening up for competitive advantage - How Deutsche telekom creates an open innovation ecosystem. R\&D Management, 39(4), 420-430. https://doi.org/10.1111/j.1467-9310.2009.00568.x

Santos F.M., Eisenhardt K.M. (2005) Organizational boundaries and theories of organization. Organization Science, 16(5), 491-508.

https://doi.org/10.1287/orsc.1050.0152

Sarkar S., Costa A.I.A. (2008) Dynamics of open innovation in the food industry. Trends in Food Science and Technology, 19(11), 574-580. https://doi.org/10.1016/j.tifs.2008.09.006

Sieg J.H., Wallin M.W., and von Krogh G. (2010) Managerial challenges in open innovation: A study of innovation intermediation in the chemical industry. ReD Management, 40(3), 281-291. https://doi.org/10.1111/j.1467-9310.2010.00596.x

Smith G., Sochor J., Karlsson I.C.M.A. (2018) Mobility as a Service: Development scenarios and implications for public transport. Research in Transportation Economics, 69, 592-599. https://doi.org/10.1016/j.retrec.2018.04.001

Sturgeon T.J., van Biesebroeck J. (2011) Global value chains in the automotive industry: An enhanced role for developing countries? International Journal of Technological Learning, Innovation and Development, 4(1-3), 181-205. DOI: 10.1504/IJTLID.2011.04190

Swann P., Prevezer M. (1996) A comparison of the dynamics of industrial clustering in computing and biotechnology. Research Policy, 25(7), 1139-1157. https://doi.org/10.1016/S0048-7333(96)00897-9

Teece D.J. (2018) Profiting from innovation in the digital economy: Enabling technologies, standards, and licensing models in the wireless world. Research Policy, 47(8), 1367-1387. https://doi.org/10.1016/j.respol.2017.01.015

Thompson V., Hardash J.A.C., Decker B., Summers R.O. (2012) NASA (In)novation ecosystem: Taking technology innovation from buzz to reality. Paper presented at the 2012 IEEE Aerospace Conference, 3-10 March 2012, Big Sky, MT, USA. DOI: 10.1109/AERO.2012.6187447.

Torre A. (2008) On the Role Played by Temporary Geographical Proximity in Knowledge Transmission. Regional Studies, 42(6), 869-889. https://doi.org/10.1080/00343400801922814

Torre A. and Zimmermann J.-B. (2015) From clusters to local industrial ecosystems. Revue d'economie industrielle, 52, 13-38, DOI: 10.4000/ rei.6204.

Traitler H., Watzke H.J., Saguy I.S. (2011) Reinventing R\&D in an Open Innovation Ecosystem. Journal of Food Science, 76(2), R62-68, https://doi.org/10.1111/j.1750-3841.2010.01998.x

Walsh J.P., Lee Y.N., Nagaoka S. (2016) Openness and innovation in the US: Collaboration form, idea generation and implementation. Research Policy, 45(8), 1660-1671. https://doi.org/10.1016/j.respol.2016.04.013

West J., Bogers M. (2014) Leveraging external sources of innovation: A review of research on open innovation. Journal of Product Innovation Management, 31(4), 814-831. https://doi.org/10.1111/jpim.12125

West J., Salter A., Vanhaverbeke W., Chesbrough H. (2014) Open innovation: The next decade. Research Policy, 43(5), 805-811. https://doi. org/10.1016/j.respol.2014.03.001

Wilhelm M., Dolfsma W. (2018) Managing knowledge boundaries for open innovation - lessons from the automotive industry. International Journal of Operations \& Production Management, 38(1), 230-248. https://doi.org/10.1108/IJOPM-06-2015-0337

Wright M.,Train K. (1987) Qualitative Choice Analysis-Theory, Econometrics and an Application to Automobile Demand. The Journal of the Operational Research Society, 38(7), 665. https://doi.org/10.2307/2582403

Wu G., Inderbitzin A., Bening C. (2015) Total cost of ownership of electric vehicles compared to conventional vehicles: A probabilistic analysis and projection across market segments. Energy Policy, 80, 196-214. https://doi.org/10.1016/j.enpol.2015.02.004

Yang C.H., Motohashi K., Chen J.R. (2009) Are new technology-based firms located on science parks really more innovative? Evidence from Taiwan. Research Policy, 38(1), 77-85. https://doi.org/10.1016/j.respol.2008.09.001 